\title{
PENGAMATAN PADA PRODUKSI KACANG REMPEYEK SEBAGAI SUMBER BELAJAR IPS
}

\author{
Isna Fitriani \\ Pendidikan IPS FKIP Universitas Lambung Mangkurat \\ $\underline{1810128320012 @ \text { mhs.ulm.ac.id }}$
}

\begin{abstract}
ABSTRAK
Tujuan dari pengamatan ini adalah mendiskripsikan nilai pendidikan pada produksi kacang rempeyek di Desa Kaliring Kabupaten Hulu Sungai Selatan sebagai sumber belajar IPS di SMP. Pengamatan ini dilakukan dengan metode penelitian kualitatif. Pengumpulan data dilakukan melalui wawancara, observasi dan dokumentasi. Teknik analisis data dilakukan dengan reduksi data, penyajian data dan penarikan kesimpulan. Hasil hasil penelitian menunjukkan bahwa kegiatan produksi dilakukan dengan bertahap seperti membuat sambal, membuat adonan kacang rempeyek, kemudian dilanjutkan dengan pembuatan kacang rempeyek. Kegiatan Distribusi dilakukan dengan cara pengantaran dari warung ke warung. Pemanfaatan kegiatan produksi dan distribusi pada pembuatan kacang rempeyek relevan sebagai sumber pembelajaran IPS pada materi kegiatan ekonomi.
\end{abstract}

Kata Kunci : Kacang rempeyek, sumber belajar, IPS

\section{PENDAHULUAN}

Makanan memang sesalu menjadi bahan pokok yang di konsumsi manusia. Seperti halnya dengan makanan kacang rempeyek yang bisa dijadikan snack untuk menemani makan dengan nasi. Kacang rempeyek merupakan sejenis makanan pelengkap dari kelompok gorengan. Secara umum, kacang rempeyek adalah gorengan tepung beras atau bisa juga tepung gandum yang dicampur dengan air hingga membentuk adonan agak encer, diberi bumbu terutama garam dan bawang putih dan diberi bahan pengisi yang khas, biasanya biji kacang tanah. Peran tepung di sini adalah sebagai pengikat kacangnya agar tidak berhamburan.

Produksi kacang rempeyek biasanya dibuat dalam skala rumahan yaitu yang dilakukan secara kecil-kecilan yang jumlah karyawannya hanya sedikit. Karyawan ini dalam artian mereka yang bekerja dalam proses pembuatan kacang rempeyeknya. Jumlah karyawan mereka kisaran 2 sampai 5 orang karyawan saja. kebanyakan mereka yang memproduksi kacang rempeyek ini bisa untuk mencukupi kebutuhan hidup mereka baik dari karyawannya maupun yang mempunyai rumah produksi tersebut. 
Untuk pengamatan kali ini saya mengamati yang berkaitan dengan penjelasan diatas yaitu pengamatan pada produksi kacang rempeyek. Dalam pengamatan ini saya melakukan di Desa Kaliring Kecamatan Padang Batung Kabupaten Hulu Sungai Selatan. Di Desa Kaliring ini ada beberapa rumah produksi yang memproduksi kacang rempeyek sebagai mata pencahariannya. Ada kurang lebih 6 rumah produksi yang membuat kacang rempeyek di desa Kaliring ini. Meskipun banyak yang memproduksi tetapi mereka mempunyai tujuan pengantaran masingmasing. proses pemasarannya pun tujuan pengantarannya ada yang sama daerah pengantarannya dan ada juga yang berbeda. Tujuan pengantarannya pun berbeda-beda ada yang mengantar ke warungwarung, pasar, dan juga ke toko-toko.

\section{METODE PENELITIAN}

Penelitian ini menggunakan metode kualitatif, karena fokus yang dikaji tentang kegiatan produksi, produksi dan konsumsi pada pembuatan kacang rempeyek dalam pemanfaatannya sebagai sumber belajar IPS. Sehingga metode penelitian kualitatif ini cocok sebagai desain penelitian. Menurut pendapat Bogdan dan Tailor metode penelitian yang menghasilkan data deskriptif yang berupa kata-kata tertulis atau lisan dari gejala-gejala yang diamati. Pendekatannya diarahkan pada latar individu tersebut secara menyeluruh (Jumriani, J. 2018). Penelitian ini dilakukan di Desa Kaliring Kabupaten Hulu Sungai Selatan. Data yang dimasukkan saat dilapangan yaitu pengamatan secara langsung. Teknik pengumpulan data dalam penelitian ini, meliputi wawancara, observasi, dan studi dokumentasi. Sumber data terdiri dari pekerja, pembeli, pedagang, orang yang menyalurkan produksi kacang rempeyek tersebut.

\section{HASIL PENELITIAN DAN PEMBAHASAN}

\section{A. Produksi Kacang Rempeyek}

Rempeyek merupakan jenis makanan yang terbuat dari adonan tepung yang dilengkapi dengan bumbu-bumbu yang membuat rempeyek itu enak dan juga dibuat kacang di tengah-tengah . Rempeyek ini termasuk juga gorengan yang bisa dinikmati dalam berbagai hidangan. Kacang rempeyek bisa menjadi bahan pelengkap nasi, gado-gado, pecal dan juga rujak. Kacang rempeyek ini juga bisa ditambah dengan varian rasa udang, ikan-ikan laut, ikan air tawar pun 
juga bisa. Bahkan sekarang ada rempeyek yang varian sayur-sayuran seperti daun jeruk bahkan daun bayam (Mumpuni, S. 2013).

Kacang rempeyek yang di bahas kali ini yaitu jenis makanan yang berbentuk bulat dan kumpulan kacangnya itu berada ditengah-tengah. Bahan dasar dari pembuatan kacang rempeyek ini yaitu menggunakan kacang, tepung dan bumbu-bumbu yang membuat rempeyek ini menjadi enak dan khas. Jenis kacang yang di produksi ini yaitu kacang tanah. Adapun untuk tepungnya dalam pembuatan ini yaitu menggunakan tepung gandum. Kacang rempeyek ini dibuat dengan rasa asin-manis dan ditambah dengan ketumbar untuk penciptakan kekhasan nya.

Ilmu Pengetahuan Sosial (IPS) merupakan salah satu mata pelajaran yang diberikan mulai dari jenjang pendidikan dasar hingga menengah mengkaji seperangkat peristiwa, fakta, konsep dan generalisasi yang berkaitan dengan isu sosial. Pada jenjang SMP/MTs mata pelajaran IPS memuat materi Geografi, Sejarah, Sosiologi dan Ekonomi. Dalam pelaksanaannya proses pembelajaran haruslah menyenangkan dan mendorong siswa menjadi aktif agar pembelajaran menjadi bermakna. Untuk itu kualitas proses belajar mengajar harus terus diperbaiki, agar hasil belajar siswa lebih optimal (Arif, M. 2020).

\section{B. Pelaksanaa Observasi produksi Kacang Rempeyek}

\section{Waktu Pelaksanaan Observasi}

Observasi dilaksanakan di Desa Kaliring Kecamatan Padang Batung Kabupaten Hulu Sungai Selatan. Pelaksanaan observasi ini dilakukan pengamatan sebanyak tiga kali yaitu pada pengematan pertama mengamati cara pembuatan kacang rempeyek dan melakukan wawancara pada karyawan yang membuat kacang rempeyek tersebut. Pada pengamatan kedua yaitu melakukan pengamatan untuk cara pengemasannya sambil melakukan wawancara juga. Pada pengamatan ketiga yaitu melakukan pengamatan pada pemasaran kacang rempeyek ini dan melakukan wawancara kembali mengenai pemasaran kacang rempeyek tersebut.

\section{Hasil dan Pembahasan}

Kacang rempeyek merupakan jenis makanan pelengkap pada nasi. Dengan rasanya yang renyah dan nikmat untuk pada saat memakannya. 
Dilengkapi dengan rasa rempeyek yang sengaja dibuat asin tetapi juga ditambah juga rasa manis-manisnya dan di tambah juga dengan rasa ketumbar untuk melengkapi kenikmatan kacang rempeyek. Kalau orang yang suka dengan kacang rempeyek makan satu rempeyek pun tidak cukup satu kali makan karena rasaya yang gurih dan nagih.

Saat melakukan pengamatan ke salah satu tempat produksi kacang rempeyek di Desa Kaliring. Penulis melakukan pengamatan produksi kacang rempeyek yang dimiliki oleh ibu Hartati. Pengamatan pertama penulis bertemu orang yang bekerja/karyawan Ibu Hartati sebagai pembuat kacang rempeyek. Jadi, karyawan yang kacang rempeyek ini sebenarnya ada tiga orang tetapi ada satu karyawan bekerja berpindahpindah dan yang dua karyawan lagi merupakan karyawan tetap.

Bahan dasar dalam pembuatan kacang rempeyek ini sudah tidak asing lagi kita temui di bahan dapur. Tepung gandum merupakan utama yang digunakan untuk membuat kacang rempeyek. Menurut pengamatan penulis gandum yang digunakan yaitu gandum cap Lencana merah jadi. Kacang tanah juga bahan dasar dari produksi ini. Kacang tanah ini sekali beli langsung satu karung sekitar 1 ton. Adapun alat-alat yang digunakan untuk membuat kacang rempeyek ini yaitu, dapur bagi pembuatan dengan kayu, cetakan kacang rempeyek yang membuat rempeyeknya itu jadi bulat, wajan besar, minyak kelapa sawit, dll.

Dari hasil wawancara dengan karyawan cara pembuatan kacang rempeyek pertama-tama membuat adonan terlebih dahulu dari tepung yang sudah dicampur dengan bumbu-bumbu untuk menambah rasa diaduk sampai terlihat encer. Setelah diaduk kemudian sediakan cetakan dan wajan besar diatas api sampai panas. Pastikan apinya panas lalu adonan tadi diambil dengan centongan kecil buat juga kacang tanahnya di campur dengan adonan tadi di dalam centongan setelah itu adonan dan kacang tadi dibuat kedalam cetakan. Biarkan sampai berbentuk bulat dan bisa diangkat. Kemudian setelah sedikit keras dan bisa diangkat lalu digoreng lagi ke wajan yang besar sampai benar-benar matang. 
Saat melakukan wawancara pada pekerja jadi ada dua pekerja saat penulis melakukan pengamatan. Untuk pekerja bisa memproduksi dua sampai tiga kilo dalam sehari. Para pekerja untuk pergi ke tempat pembuatan kacang rempeyek tersebut pada sekitar jam enam pagi-pagi. Dan juga setiap sepuluh hari sekali mereka mengambil gaji. Padahal mengambil gaji bisa diambil setelah selesai membuat kacang rempeyek tersebut dalam satu kilo tepung mendapat upah Rp.15.000,00.

Saat pengamatan observasi pada teknik pengemasan dilakukan oleh pemilik produksi sendiri. Pada saat melakukan pengemasan biasanya dilakukan pada sore hari sekitar habis ashar. Pengemasan tersebut dikemas disesuaikan dengan pengantaran hari esok. Pengemasan kacang Rempeyek ini dibungkusnya dengan plastik. Jadi dalam satu bungkus itu isinya ada delapan keping. Dalam satu bungkus tersebut di hargai dengan Rp. 8000,00 perbungkus. Adapun teknik pemasarannya, dilakukan dengan pengantaran dari warung ke warung. Jadi pada saat pengantaran awalnya menawarkan kacang rempeyeknya dari warung ke warung. Pengantarannya juga tidak setiap hari tetapi pengantarannya pada hari senin, rabu, kamis dan sabtu dan itu pengantarannya berbeda-beda tempat.

\section{Nilai Pendidikan Pada Produksi Kacang Rempeyek sebagai Sumber Belajar IPS}

Ilmu Pengetahuan Sosial (IPS) merupakan integrasi dari berbagai cabang ilmu-ilmu sosial seperti : sejarah, geografi, ekonomi, politik, hukum, dan budaya. Ilmu pengetahuan sosial dirumuskan atas dasar realitas dan fenomena sosial yang mewujudkan suatu pendekatan interdisipliner dari aspek dan cabang-cabang ilmu pengetahuan sosial (sejarah, geografi, ekonomi, politik, hukum, dan budaya). Ilmu pengetahuan sosial atau studi sosial itu merupakan bagian dari kurikulum sekolah yang diturunkan dari isi materi cabang-cabang ilmu sosial : sejarah, geografi, ekonomi, politik, antropologi, filsafat, dan psikologi sosial (Syukron, B. 2017).

Menurut (Dahar, 2011), Pembelajaran bermakna merupakan suatu proses mengaitkan informasi baru pada konsep-konsep relevan yang terdapat dalam struktur kognitif seseorang. Struktur kognitif tersebut meliputi fakta, 
konsep, dan generalisasi yang telah dipelajari peserta didik. Melalui integrasi nilai-nilai dalam pendidikan IPS akan memberikan bekal kepada peserta didik tentang mengembangkan diri dalam kehidupannya. Pendidikan IPS membekali peserta didik tentang pengetahuan, keterampilan, sikap, nilai, sehingga dapat membentuk citra diri peserta didik menjadi manusia yang memiliki jati diri yang mampu hidup ditengah masyarakat dengan damai dan dapat memberikan manfaat kepada orang lain (Nasih, M., Abbas, E. W., \& Syaharuddin, S. 2019).

Menurut Suwarma Al Muchtar (2015) mengemukakan bahwa sumber daya belajar perlu dilakukan transformasi sikap dan perilaku dari kebiasaan menggunakan sumber daya belajar terbatas pada buku pelajaran sebagai satu-satunya sumber kepada penggunaan aneka media, dari kebiasaan tatap muka di kelas kearah optimalisasi sumber daya belajar yang ada dilingkungan sekolah dan peserta didik, perlu dibudayakan menjadikan masyarakat sebagai sumber media belajar. Definisi Sumber belajar secara luas dapat diartikan sebagai buku atau bahan ajar dalam bentuk cetak lainnya, seperti jurnal ilmiah, koran, buletin, majalah, dan lain-lain (ABBAS, E. W., Hidayat Putra, M. A., \& Noor Handy, M. R. 2019).

Inovasi-inovasi dalam pendidikan IPS telah dilakukan melalui eksplorasi sumber belajar IPS dengan memanfaatkan potensi lokal. Potensi lokal dalam pembelajaran IPS bisa dilakukan dengan memanfaatkan potensi lingkungan sekitar, sehingga peserta didik mampu mewujudkan kesadaran sosial menuju masyarakat demokratis dan tanggung jawab. Potensi lokal juga bisa digali melalui aktivitas yang memunculkan nilai yang bermanfaat bagi praktik pendidikan (Subiyakto, B., \& Mutiani, M. 2019).

Materi tentang kegiatan ekonomi pada pembelajaran IPS merupakan materi yang dapat diintegrasikan pada kagiatan produksi, distribusi dan konsumsi. Pada kegiatan Produksi terletak pada pembuatan kacang rempeyek. kegiatan distribusi terletak pada kegiatan pemasaran atau pengantaran kacang rempeyek dari warung ke warung hal ini dengan tujuan untuk menyalurkan kacang rempeyek ke konsumen. Pada kegiatan konsumsi 
yaitu orang-orang yang membeli kacang rempeyek tersebut untuk memenuhi kebutuhan konsumen.

\section{SIMPULAN}

Kacang Rempeyek ini merupakan makanan yang bisa dimakan dengan nasi. Kacang rempeyek ini termasuk sejenis gorengan yang bisa dimakan dengan sendiri. Tapi bagi penikmat kacang rempeyek ini tidak bisa dimakan banyak-banyak karena termasuk juga gorengan yang bisa kurang baik untuk kesehatan tubuh. Membuat kacang rempyek ini dalam sekilonya sekitar dua setengah jam baru selesai. Kekhasan dari kacang rempeyek yang penulis amati ini terletak pada bumbu kacang rempeyek ini sendiri. Diantara bumbu dasarnya adalah kencur, bawang putih, ketumbar, penyedap rasa, dan garam. Pembuatan kacang rempeyek ini di desa Kaliring lumayan banyak sebenarnya. Tetapi banyak yang sekedar membuat tetapi tidak di resmikan seperti membuat sertifikat halal terhadap makanan. Padahal produksi kacang rempeyek ini bisa jadikan Desa Produksi. Teknik pemasarannya pun masih terbilang tradisional karena masih pengantarannya dari warung ke warung. Inovasi teknik pengantaran ini bisa juga diperbarui dengan sistem online seperti memasarkan lewat media sosial instagram, facebook, dan media sosial lain yang berpotensi untuk menjual kacang rempeyek secara online.

\section{DAFTAR PUSTAKA}

ABBAS, E. W., Hidayat Putra, M. A., \& Noor Handy, M. R. (2019). Laporan Penelitian: PEMANFAATAN EKOWISATA SUNGAI MARTAPURA KOTA BANJARMASIN SEBAGAI SUMBER BELAJAR IPS.

Abbas, E. W. (2013). Mewacanakan Pendidikan IPS. Mewacanakan Pendidikan IPS. Arif, M. (2020). PENERAPAN MODEL PEMBELAJARAN KOOPERATIF TEAMS GAMES TOURNAMENT UNTUK MENINGKATKAN PEMAHAMAN KONSEP KEGIATAN EKONOMI. Didaktikum, 20(3).

DEWA, P. B., SUDARTA, I. W., \& HANDAYANI, M. T. Tingkat Penerapan dan Pengetahuan Wanita Tani Tentang Industri Rempeyek pada Kelompok Wanita Tani Mekar Sari di Desa Bukian Kecamatan Payangan Kabupaten Gianyar. Jurnal Agribisnis dan Agrowisata (Journal of Agribusiness and Agritourism).

Jumriani, J. (2018). KEGIATAN PRODUKSI DAN DISTRIBUSI DI KAMPUNG SASIRANGAN SEBAGAI SUMBER BELAJAR IPS. Jurnal Socius, 7(1). 
Mumpuni, S. (2013). PELATIHANPENYEMPURNAAN PRODUK PEYEK REBON. Asian Journal of Innovation and Entrepreneurship, 2(03), 154157.

Nasih, M., Abbas, E. W., \& Syaharuddin, S. (2019). Nilai-Nilai Haul Guru Sekumpul Sebagai Sumber Belajar IPS. Jurnal Socius, 8(2).

Norhayati, N., Abbas, E. W., \& Putra, M. A. H. (2019). Social Interaction Pattern Jelai Riverbanks South Basirih. The Innovation of Social Studies Journal, 1(1), 12-20.

Subiyakto, B., \& Mutiani, M. (2019). Internalisasi nilai pendidikan melalui aktivitas masyarakat sebagai sumber belajar ilmu pengetahuan sosial. Khazanah: Jurnal Studi Islam dan Humaniora, 17(1), 137-166.

Syukron, B. (2017). MODEL PEMBELAJARAN ILMU PENGETAHUAN SOSIAL (IPS). Tarbawiyah: Jurnal Ilmiah Pendidikan, 12(01), 111-136. 